\title{
The Relationship Between The Characteristics Of School-Age Children And The Incidence Of Bullying At SDN 31 Bontoraja
}

\author{
Nurkasanita $^{1}$, Fitriani $^{2 *}$, Haerani $^{3}$ \\ 1,Nursing Student, Stikes Panrita Husada Bulukumba, Indonesia \\ ${ }^{2,3}$ Departement of Nursing, Stikes Panrita Husada Bulukumba, Indonesia
}

*Corresponding author: Fitriani

Email: fitrianivivi@gmail.com

\begin{abstract}
ABSTRAC
The incidence of bullying in schools is not something new anymore. However, until now the incident of bullying has not been handled specifically. While it is known that bullying is a trigger for acts of violence against children. Violence is one form of action in the form of physical force, threats, or certain associations with the intention to hurt and cause physical or mental injury. Bullying is defined as suppression that is carried out intentionally, aggressively, which is carried out strongly by an individual or group. There are several factors that can influence the incidence of bullyingin children, including the characteristics of the child itself. The purpose of this study was to determine the relationship between the characteristics of children and the incidence of bullying at SDN 31 Bontoraja. This research method uses an analytical observational design with a Cross Sectional approach. With a total sample population of 71 and the number of samples as many as 41 people. This research uses a sampling technique, namely probability sampling using a simple random sampling technique, also called simple. In this study, the results showed that for a low level of bullying as many as 19 people and a high level of bullying as many as 22 people. And the results of the bivariate analysis using the chi-square test obtained results for the three independent variables, namely the level of age, gender, and family environment that H0 was accepted. In this study it can be concluded that the characteristics of school-age children consisting of age, gender, and family environment have no relationship with the incidence of bullying. Parents always control their children in socializing, using electronic and print media, for example parents taking their children to school, accompanying their children to watch television.
\end{abstract}

Keywords: Characteristics, School-Age Children, Bullying 


\section{PENDAHULUAN}

Kejadian bullying disekolah sudah bukan hal yang baru lagi. Akan tetapi, sampai saat ini kejadian bulliyng belum ditangani secara khusus. Sedangkan diketahui bahwa bullying merupakn pemicu tindakan kerasan pada anak. Kekerasan merupakan salah satu bentuk tindakan dalam bentuk kekuatan fisik, ancaman, atau perkumpulan tertentu dengan niat untuk menyakiti dan menimbukan cedera secara fisik maupun mental (Arya, 2018).

Bullying diartikan sebagai penindasan yang dilakkan secara segaja, bersifat agresif, yang dilakukan secara kuat yang dilakukan oleh individu atau kelmpok. Sekitar 30\% dari sekolah menengah dan atas di Amerika serikat terlibat dlam kasus intimidasi dan tindakan bullying, termasuk 13\% sebagai pelaku bullying, 11\% sebagai korban tindakan bulying, dan sekitar 6\% berperilaku keduanya yaitu sebgai pelaku dan korban bulying. Secara internasional, keterlibatan dalam tindakan intimidasi dan bulying berkisar sekitar 9\% hingga 54\%, kemudian sekitar 3\% sampai $20 \%$ sebagai pengganggu, 5\% sampi $20 \%$ sebagai korbn penindasan, dan untk bentuk-bentuk penindasan berbagai bentuk. Korban bulying akan mengalami kecemasan emosional yang besar, depresi, serta penurunan harga diri, dan cenderng akan mengalami isolasi sosial (Shetgiri, 2012).

Dalam survey yang di lakukan UNESCO pada tahun 2019 menunjukkan bahwa bullying terjadi berbagai Negara dengan presentase terendah 7\% di Tajikistan dan tertinggi $74 \%$ di samoa. Data KPAI yang dirilis kebali pada 23 juli 2018 menunjukan bahwa sampai mei 2018 terjadi 36 kasus bullying, yang jika di presntasikan merupakan 22,4\% dari 161 kasus yang terjadi dibidang penidikan.(Muhopilah \& Tentama, 2019).

Prevlensi di Indonesia menunjukan bahwa siswa yang menjadi pelaku bullying meningkat dari 67 kasus menjadi menjadi 69 kasus, sedangkan untuk yang menjadi korban bulying $40 \%$ pada usia 13-15 tahun mengaakan pernah mengalami kerasan dari teman sebayanya, dan $50 \%$ anak mengalami perundungan (Khoirunnisa et al., 2018).

Belum terdapat banyak konteks yang berbicara terkait dengan kejadan bullying, beberapa penelitian tentang bullying dilakukan disekolah, dimana sekolah merupkan tempat anak-anak untuk melakukan intersi dengan dunianya. Namun pada masa sekarang, kejadian bullying bukan hanya terjadi dilingkngan sekolah (secara langsung) namun trdapat beberapa pembulyan dilakukan di dunia maya (media sosial) (Golmaryami, 2015). 
Beberapa peneliti telah melakukan penelitian terkait dengan factor yang menjadi penyebab bullying dintaranya yaitu factor dimana anak menuntut ilmu (sekolah). Bayak hal yang menjadi pendukung terjadinya bullying disekolah salah satunya yaitu karakteristik sekolah, kualitas guru, dan urbanisasi. Korban bullying disekolah akan meraskan tidak dihargai, tidak diharapkan, tidak dihormatidan merasa diberlakukan tidak adil.

Bullying mmiliki beberapa dampak negtive bagi perkembangan karakter anak, baik kepada pelaku maupun kepada korban. Korban bullying akan menerima berbagai jenis perlakan baik secara fisik maupun yang akan merusak mental

Terdapat beberapa faktor yang dapat berpengaruh dengan kejadian bullying pada anak diantaranya yaitu karakteristik anak itu sendiri.dalam sebuah peneitian yang dilakukan di United States didapatkan hasil bahwa anak-anak berusia 10-17 tahun prevalnsi untuk bullying sebesar 14,9\%. (Shetgiri, 2012).

Dalam survey yang dilakukn pada tahun 2009-2010 menunjukkan hasil bahwa di negara Eropa, Canada, dan USA didapatkan prevalensi kejadian bulying sekitar 2\% smpai 32\% dan sekitar 1\% sampai 26\% dalam kasus perbatan bullying(Babarro, 2020).

Dalam peneitian yang dilakukan oleh Marizki tahun 2018 kejadian bullying di Sumatra Barat terdapat 872 kasus. Menurut ketua KPAI Asroun Niam, pada tahun 2016 kasus kekerasan pada anak terutama prilaku bullying dari 5.066. KPAI juga menemukan bahwa anak mengalami bullying di lingkngan sekolah sebesar 87, 6\%, di lakukan oleh guru 29, 9\%, 42, 1\% dilakukan oleh teman kelas, dan 28, 0\% di lakukan oleh teman lainya (Marizki, 2018).

Hasil penelitian yang dilkukan oleh (Devita \& Dyna, 2019) yang dilakukan pada seluruh SD ngeri di kota pekanbaru menunjukan bahwa ada hubungan antara karakteistik anak yang terdiri dari tingkatan usia, jenis kelamin, kelas, pekeraan dan pengahasilan orang tua dengan kejadian bullying pada anak dngan usia sekolah. Hasil analisis multivariate menunjukkan bahwa karateristik tingkatan kelas menjadi hal yang paling kuat hubungannya terhdap kejadian bullying pada anak.

Penelitian lain yang dilakuan oleh (Rohman, 2016) menunjukkan hasil yang sama bahwa ada hubugan antara karakteristik tingkatan kelas dan jenis kelamin anak terhadap kejdian bullying pada anak usia sekolah. 
Penelitian yang dilakuan oleh (Shetgiri, 2012) tentang karakteristik orang tua dengan kejadian bulying didapatkan hasil Anak-anak Afrika, Amerika Latin yang hidup dlam kemiskinandan yang memiliki masalah emosional, perkembangan, atau perilaku (EDB)kemungkinan bullying yang lebih tinggi, seperti halny anak-anak dari orang tua yang merasa marah dengan anak merekatau yang merasa anak mereka sangat menganggu mereka atau sulit untuk dirawat; suboptimalkesehatan mental ibu dikaitkan dengan kemungkina bulying yang lebih tinggi.

Penelitian tentang hubungan karaktristik anak dengan kejadian bullying didapatkan hasil bahwa 9,3\% dari anak-anak menjadi korban, 1,4\% pengganggu dan 1,6\% korban perundunga. Hasil penelitian menunjukkan bahwa semakin tinggitingkat attenion deficit hyperactivity disorder symptomatolog meningkatkan risiko bullying,sedangkan sampel yang memiliki hubungn yang 1 baik dengan orang tua dan dukungan sosial yang kuat memiliki risiko terkena bulying yang lebih rendah. Kemudian untuk anak-anak yang memiliki hubngan teman sebaya yang kuat dan dukungan sosial yang tinggi juga meiliki resiko yang lebih rendah untuk terkena bullying(Babarro et al., 2020).

Penelitian lain yang dilakuan terkait Hubungan Kepercayaan Diri Dan Dukungan Teman Sebaya Dengn Jenis Perilaku Bullying Di Mtsn Lawang Mandahling Kecamatan Salipaung Tahun 2017 di dapatkan hasil bahwa Hasil dari Uji statistik bawa terdapat hubungan antara rasa percaya diri teman sebaya dengan tipePerilaku bullying. Implikasi dari hasil penelitian menunjukan jenisjenis perilaku Bullyingmemiliki peran penting dalam perilaku Bullying(Putri, 2018).

Dampak bulying dapat mengancam setiap pihak yang terlibat, diantaranya dampak bagi korban yaitu depresi, marah, rendahnya tingkat kehadiran, rendahya prestasi akademik siswa dan kemampuan analisa siswa. Dampak bagi pelaku yaitu memilki rasa percaya diri yang tinggi, bersifat agresif dengan prilaku yang pro terhadap kekerasan, muda marah, dan toleansi yang rendah terhadap frusasi. Sedangkan dampak bagi siswa lain yang menyaksikan bulling dapat berasumsi bahwa bullying adalah prilaku yng diterimah secara sosial, sehingga siswa ingin bergabung menjadi penindas karna takut menjadi sasaran berikutnya. Selain itu Salah satu dampak buruk yang disebbkan dari tindakan bullying adalah perubahan mental yang dirasaan oleh anak, dimana jika tidak segera ditangani akan berdampak menjadi gangguan mental pada anak (Syukri, 2020). 
Berdasarkan hasil pengambilan data awal yang dilakukan di SD negeri 31 bontoraja kepada kepala sekolah, bahwa jumlah keseluruhan siswa-siswi di SD-nya berjumlah 349, dimana fokus penelitian akan dilakukan pada siswa dan siswi kelas 5 dan kelas 6 dengan jumlah keseluruhan yaitu 71 orang. Dimana kelas 5 berjumlah 39 orang dengan kriteria yang berjenis kelamin perempuan berjumlah 24 orang dan yang berjenis kelamin laki-laki berjumlah 15 orang. Sedangkan untuk kelas 6 dengan jumlah keseluruhan yaitu 32 orang dengan kriteria siswa yang berjenis kelamin perempuan berjumlah 20 orang dan yang berjenis kelamin laki-laki 12 orang. Berdasarkan survey awal yang dilaukan peneliti kepada beberapa siswasiswi terkait dengan tindakan bulying, didapatkan hasil bahwa beberapa siswa mendapatkan tindakan bulying secara verbal, sosial, danfisik. Dimana tindakan bullying secara verbal salah satunya adalah mengganggu siswa lain dengan mengatkan sesuatu yang buruk, tindakan bulyingsosial salah satunya adalah meminta teman untuk melwan siswa lain, dan bulying fisik adalah sengaja menabrak siswa lain ketika mereka berjalan.

Berdasarkan dari uraian diatas maka peneliti tertarik untuk melakukan penelitian tentang "hubungan karakteristik anak usia sekolah dengan kajadian bullying di SD NEGERI 31 BONTORAJA".

\section{METODE PENELITIAN}

\section{Desain Penelitian}

Desain penelitian yang digunakan dalam penelitian ini adalah pengamatan analitis dengan pendekatan cross sectional. Dalam pendekatan cross sectional, yaitu data yang dikumpulkan sesaat atau data yang diperoleh saat ini, metode ini dilakukan dengan melakukan hasil survei, wawancara, atau dengan mendistribusikan kuesioner kepada responden penelitian (Nursalam, 2017).

\section{Populasi dan Sampel}

Populasi dalam penelitian ini berjumlah 71 siswa di kelas 5 dan 6 di SD 31 Bontoraja. Sampel yang diperoleh dalam penelitian ini adalah 41 sampel dengan teknik sampling yang diperoleh menggunakan rumus Isaac dan Michael (Sugiyono, 2014). Teknik sampling dalam penelitian ini adalah metode probability sampling menggunakan teknik sampling, yaitu simple random sampling, juga disebut simple (simple), dengan metode sampling yang dilakukan dengan memilih semua atau setiap individu yang bertemu dan telah memenuhi apa yang telah ditentukan dalam seleksi. sampai jumlah sampel yang diperlukan dapat dipenuhi (Dharma, 2017). 


\section{Instrument Penelitian}

Instrument penelitian adalah alat ukur yang digunakan oleh peneliti yang digunakan untuk mengoservasi, mengukur atau menilai suatu fenomena dan juga secara tertulis berupa pedoman wawancara, pengamatan, dan daftar yang terdiri dari beberapa pertanyan yang sudah disiapkan oleh peneliti untuk mendaptkan informasi yang dibutuhkan dari responden (Nursalam, 2017). Untuk kuisoner anak Karakteristik anak, Kuisioner berisi data identitas dan karakteritik anak. Data identitas berisi nomor responden, nama, umur, dan jenis kelmin. Sedangkan pernyataan karakteristik anak berjumlah 13 pernyatan. Cara pengisian kosioner pernyataan karakteristik anak dengan memberikan tanda $(\sqrt{ })$ jika, pernyataan tidak pernah (TP) skor 1, kadang-kadang (KD) skor 2, sering (S) skor 3, dan sering sekali (SS) skor 4. Pernyataan tentang bahasa anak (nomor 1,2, dan 3), pernyataan tentang struktur keluarga (nomor 4 ), pernyataan tentang perubahan sosial-emosonal (nomor 5, 6, 7, 8, 9, dan 10), dan pernyatan tentang lingkungan keluarga (nomor 11, 12 dan 13).

Kuisioner Bulliying berisi data dan kejadian bullying. Data identitas berisi nomor responden, nama, umur, dan jenis kelamin. Sedangkan pernyataan kejadian bullyingberjumlah 12 pernyataan. Cara pengisian kosioner pernyataan bullying dengan memberi tanda $(\sqrt{ })$ jika, pernyatan tidak pernah (TP) skor 1, kadang-kadang (KD) skor 2, sering (S) skor 3, dan sangat sering (SS) skor 4. Pernyatan tentang bullying verbal (nomor 1, 2, 3, 4, dan 5), pernyataan bulying sosial (nomor 6, 7, dan 8), dan pernyataan bullying fisik (nomor 9, 10, 11, dan 12).

\section{HASIL PENELITIAN}

Berdasarkan tabel 1. Menunjukkan hasil bahwa berdasarkan usia anak, anak usia 10 tahun yang menerima bullying adalah 5 orang dengan persentase 12,2\%, kemudian berusia 11 tahun yang menerima bullying adalah 15 orang dengan persentase 36,6\%, untuk usia 12 tahun 17 orang yang diintimidasi dengan persentase $41,5 \%$, sedangkan untuk usia 13 tahun jumlah yang diintimidasi adalah 4 orang dengan persentase 9,4\%. Karakteristik responden berdasarkan jenis kelamin. 
Tabel 1. Pendistribusian responden berdasarkan usia kepada siswa di SDN

Bontoraja tahun 2021

\begin{tabular}{ccc|}
\hline Umur (thn) & Frekuensi & Persentase (\%) \\
\hline 10 & 5 & $12.2 \%$ \\
11 & 15 & $36.6 \%$ \\
12 & 17 & $41.5 \%$ \\
13 & 4 & $9.8 \%$ \\
\hline Jumlah & $\mathbf{4 1}$ & $\mathbf{1 0 0 . 0 \%}$ \\
\hline
\end{tabular}

Berdasarkan tabel 2. Jenis Kelamin di SDN 31 Bontoraja Kabupaten Bulukumba menunjukkan bahwa sebagian besar responden perempuan sebesar 24 orang atau $(58,5 \%)$.

Tabel 2. Pendistribusian responden berdasarkan jenis kelamin pada siswa di SDN 31 Bontoraja tahun 2021

\begin{tabular}{ccc}
\hline Variabel & Frekuensi & Persentase (\%) \\
\hline Perempuan & 24 & $58.5 \%$ \\
Laki- Laki & 17 & $41.5 \%$ \\
\hline Jumlah & $\mathbf{4 1}$ & $\mathbf{1 0 0 . 0 \%}$ \\
\hline
\end{tabular}

Berdasarkan Tabel 3, hasilnya menunjukkan bahwa ada 22 bentuk bulliying tinggi dengan persentase 53,7 persen, sedangkan bullying rendah adalah 19 dengan persentase 46,3 persen. Setelah mengetahui data umum dalam penelitian ini, hasil berikut akan ditunjukkan dengan data khusus yang meliputi kode bullying di SDN 31 Bontoraja, Kecamaran Gantarang, Kabupaten Bulukumba. 
Tabel 3. Distribusi tingkat bullying di SDN 31 Bontoraja pada tahun 2021

\begin{tabular}{lcc}
\hline Variabel Bulliying & Frekuensi & Persentase (\%) \\
\hline Tinggi & 22 & $53.7 \%$ \\
Rendah & 19 & $46.3 \%$ \\
\hline Jumlah & $\mathbf{4 1}$ & $\mathbf{1 0 0 . 0 \%}$ \\
\hline
\end{tabular}

Berdasarkan hasil tes yang dilakukan, dapat disimpulkan bahwa berdasarkan tingkat usia, kecenderungan tertinggi untuk bullying terjadi pada usia 11 tahun, berjumlah 8 orang, kemudian untuk bullying rendah, yang paling banyak terjadi pada anak usia 13 tahun, dan untuk nilai nilai, hasilnya adalah 0,612. artinya Ho diterima, sehingga dapat disimpulkan bahwa tidak ada hubungan yang signifikan antara karakteristik usia dan kejadian bullying.

Tabel 4. Hubungan Antara Usia Dan Kejadian Bullying Di SDN 31 Bontoraja

\begin{tabular}{|c|c|c|c|c|c|c|c|}
\hline \multirow{3}{*}{ Umur (Tahun) } & \multicolumn{4}{|c|}{ Kejadian Bullying } & & & \multirow{3}{*}{ P Value } \\
\hline & \multicolumn{2}{|c|}{ Tinggi } & \multicolumn{2}{|c|}{ Rendah } & \multicolumn{2}{|c|}{ Jumlah } & \\
\hline & $(\mathbf{N})$ & $(\%)$ & $(\mathbf{N})$ & $(\%)$ & $(\mathrm{N})$ & $(\%)$ & \\
\hline 10 & 1 & 2.4 & 4 & 9.7 & 5 & 12.1 & \\
\hline 11 & 8 & 19.5 & 7 & 17.0 & 15 & 36.5 & \\
\hline 12 & 7 & 17.0 & 10 & 24.3 & 17 & 41.4 & 0.612 \\
\hline 13 & 2 & 4.8 & 2 & 4.8 & 4 & 9.7 & \\
\hline Jumlah & 18 & 43.7 & 23 & 55.8 & 41 & 100 & \\
\hline
\end{tabular}

kecenderungan untuk bentuk bullying yang tinggi paling sering terjadi pada wanita dengan 10 orang dan 8 orang pada pria. Kemudian ada 9 bentuk bullying rendah pada responden lakilaki dan 14 responden perempuan dengan nilai p 0,72 3 maka Ho diterima, artinya tidak ada hubungan yang signifikan antara gender dan bullying. 
Tabel 5. Hubungan antara Jenis Kelamin dan kejadian bullying di SDN 31 Bontoraja

\begin{tabular}{|c|c|c|c|c|c|c|c|}
\hline \multirow{3}{*}{ Jenis Kelamin } & \multicolumn{4}{|c|}{ Kejadian Bullying } & & & \multirow{3}{*}{$P$ Value } \\
\hline & \multicolumn{2}{|l|}{ Tinggi } & \multicolumn{2}{|c|}{ Rendah } & \multicolumn{2}{|c|}{ Total } & \\
\hline & $(\mathbf{N})$ & $(\%)$ & $(\mathbf{N})$ & $(\%)$ & $(\mathbf{N})$ & $(\%)$ & \\
\hline Wanita & 10 & 24.3 & 14 & 34.1 & 24 & 58.5 & \\
\hline Laki- Laki & 8 & 19.5 & 9 & 21.9 & 17 & 41.4 & 0.723 \\
\hline Total & 18 & 43.8 & 23 & 56 & 41 & 100 & \\
\hline
\end{tabular}

Berdasarkan hasil tes statistik menggunakan tes chi-square, dapat disimpulkan bahwa untuk lingkungan keluarga miskin jumlah anak yang terkena bullying rendah, yaitu 5 orang, kemudian untuk bullying tinggi sebanyak 4 orang, dan untuk lingkungan keluarga yang baik jumlah anak yang terkena bullying rendah, Yakni 18 orang. dan untuk bullying tinggi oleh 14 orang. Dan ditemukan p nilai 0,970. Sehingga dapat disimpulkan bahwa tidak ada hubungan antara lingkungan keluarga dan kejadian bullying.

Tabel 6. Hubungan antara lingkungan keluarga dan peristiwa Bullying di SDN 31 Bontoraja

\begin{tabular}{|c|c|c|c|c|c|c|c|}
\hline \multirow{3}{*}{ Lingkungan Keluarga } & Kej & $\mathrm{n} \mathrm{Bu}$ & & & Tota & & \multirow{3}{*}{$P$ Value } \\
\hline & \multicolumn{2}{|c|}{ Tinggi } & \multicolumn{4}{|c|}{ Rendah } & \\
\hline & $(\mathrm{N})$ & $(\%)$ & $(\mathrm{N})$ & $(\%)$ & $(\mathrm{N})$ & $(\%)$ & \\
\hline Tidak Baik & 4 & 9.7 & 5 & 12.1 & 9 & 21.9 & \\
\hline Baik & 14 & 34.1 & 18 & 43.9 & 32 & 78.0 & 0.970 \\
\hline Total & 18 & 43.8 & 23 & 56 & 41 & 100 & \\
\hline
\end{tabular}




\section{PEMBAHASAN}

Bullying didefinisikan sebagai bagian dari perilaku yang agresif, juga secara umum dapat diartkan sebagai tindakan yang dapat menimbukan cedara atau ketidaknyamnan pada individu. Biasanya kejadian bullying itu akan terjadi buerulang-ulang dengan orang yang sama dan pelaku yang sama juga. terdapat beberapa bentuk bullying yang terdapat pada kalangan anak-anak yaitu dengan adanya pembullyian yang dlakukan pada mdia sosial sehingga kekhawatiran akan semakin membesar dan menjadikan tindakan bulying dapat terjadi dengan mudah.

Korban bulying adalah orang yang mengalami penindasan, perlakuan yang dapat merugikan sehinga merasakan -penderitan baik secara isik, mental, maupun sosial (Shetgiri, 2012). Bulying adalah bentuk- bentuk perilaku kekerasan dimana terjadi pemaksan secara psikologis ataupun fisik terhadap seserang ataupun kelompok orang yang lebih lemah oleh sesorang yang lebih kuat atau seseorang yang memiliki power (kekuasaan) untuk melaukan apasaja terhadap korbannya. Korban juga mempesepsikan dirinya sebagai pihak yang lemah, tidak berdaya selalu terancam oleh bully(Olweus, 2013).

Bullying mmiliki beberapa dampak negtive bagi perkembangan karakter anak, baik kepada pelaku maupun kepada korban. Korban bullying akan menerima berbagai jenis perlakan baik secara fisik maupun yang akan merusak mental.

Terdapat beberapa faktor yang dapat menyebebkan timbulnya perilaku bullying baik berasal dari dalam diri(karakteristik anak)ataupun yang berasal dari luar diri dimana karkteristik anak yang dapat menadi salah satu faktor penyebab dari bulying yaitu usia, bahasa anak, jenis kelamin, struktur keluarga, perubahan sosialemosional dan lingkungan keluarga. Salah satu dampak yang ditimbukan dari tindakan bullying yaitu timbulnya rasa takut dan malu yng dapat menjadikan anak-anak menjadi menutup diri. Akan tetapi dmpak dari kejadian tersebut dapat dicegah jika kita telah mengetahui tandatanda anak menjadi korban bullying (Priyatna, 2017).

Bentuk bullying yang dilakukan secara kasat mata dalam artian tindakan ini dapat dilihat oleh semua orang yang terjadi karena adanya kontk secara fisik antara pelaku dengan korban. Bentuk-bentuk bullying secara fisik antara lain menampar, Menimpuk, Menginjak kaki, Menjegal, Meludahi, Memalak, Melempar korban dengan barang, Menghukum, dan Menolak untuk berteman dengan korban . 
Penelitian ini melibatkan responden dengan rentang usia 10-13 tahun, usia ini adalah usia yang paling banyak terlibat dalam perilaku bullying di tingkat sekolah dasar. Hasil penelitian ini sejalan dengan penelitian yang dilakukan oleh (Khairunisa, 2014), yang menunjukkan bahwa tidak ada hubungan yang signifikan antara usia anak-anak dan kejadian bullying. Studi lain yang sejalan dengan penelitian ini, yaitu (Kadek et al., 2015), Yang menjelaskan bahwa untuk kejadian bullying yang melibatkan anak-anak di semua tingkat usia pada pra-remaja (usia 10-12 tahun), tidak ada hubungan yang signifikan ditemukan ( $\mathrm{p}>0,05)$, hal ini dapat disebabkan karena pada tahap perkembangan ini, anak-anak mulai berinteraksi dengan lingkungan baru, mulai mengembangkan kepercayaan diri, dan mencoba untuk mencapai kompetensi penting yang harus mereka miliki. Hasil penelitian lain juga menunjukkan bahwa karakteristik usia anak-anak tidak memiliki hubungan dengan kejadian bullying. (Wakhid et al., 2017) .

Keluarga sangat bepengaruh dalam setiap pertumbuhan (secara bio-psiko-sosial-spiritual) dan perkembangan anak, bukan saja pada lingkup perkebangan fisik dengan memberikan asupan gizi yang baik akan tetpi lebih dari itu, keluarga ssangat memberikan pengaruh yang sagat besar terutama pada tahap perkembangan sosial anak. Terdpat tiga lingkup penting dalam perkembangan psikososial dimsa pra sekolah, yaitu percaya dan ketidak percayaan, pada masa bayi otonomi persis rasa malu dan ragu yang merupakan proses pengendalian diri dn rasa percaya diri, serta rasa bersalah yang menambahkan kualtas kualitas perkembangan seperti menjalankan, merencanakan dan mampu memecahkan tugas tugas demi menjadi aktif (Widyaastuti, 2019).

Pada karakteristik gender, hasil penelitian ini menunjukkan bahwa kecenderungan bullying berdasarkan jenis kelamin lebih sering terjadi pada anak perempuan sebanyak 10 orang dengan prevalensi $24,3 \%$ dibandingkan anak laki-laki sebanyak 8 orang dengan prevalensi 19,5\%. Dalam penelitian ini, nilai p-0,723 diperoleh, yang berarti bahwa tidak ada hubungan antara gender dan kejadian bullying. Penelitian ini sejalan dengan (Kadek et al., 2015), yang menunjukkan bahwa tidak ada hubungan antara jenis kelamin anak dan kejadian bullying. Berdasarkan karakteristik lingkungan keluarga, penelitian ini menemukan bahwa tidak ada hubungan yang signifikan antara lingkungan keluarga dan kejadian bullying di SDN 31 Bontoraja.. Penelitian ini sejalan dengan beberapa penelitian yang dilakukan oleh beberapa peneliti, salah satunya adalah penelitian dari (Devita \&Dyna, 2019) yang 
menunjukkan hasil bahwa tidak ada hubungan antara variabel pengasuhan, dan pekerjaan ayah dengan kejadian bullying. Penelitian lain yang sejalan dengan penelitian ini menunjukkan hasil bahwa tidak ada hubungan yang signifikan antara penerimaan keluarga dan kejadian bullying sebagaimana dibuktikan dengan nilai 0,669, keterikatan keluarga adalah ikatan yang erat dengan orang tua (Novitasari et al., 2020).

\section{KESIMPULAN DAN SARAN}

Bullying didefinisikan sebagai penindasan yang dilakukan dengan sengaja, agresif, yang dilakukan dengan kuat oleh individu atau kelompok. Dalam penelitian ini, ditemukan bahwa tidak ada hubungan antara usia, jenis kelamin, dan lingkungan keluarga dengan kejadian bullying di SDN 31 Bontoraja.

Para peneliti menyarankan orang tua untuk selalu mengontrol anak-anak mereka dalam bersosialisasi, menggunakan media elektronik dan cetak, misalnya orang tua membawa anakanak mereka ke sekolah, bertukar pendapat dengan anak-anak mereka tentang masalah yang terjadi di sekolah, menemani anak-anak mereka menonton televisi, memberikan saran, petunjuk arah dan memeriksa. menggunakan media elektronik. Dan bagi lembaga pendidikan, Lembaga Pendidikan harus selalu melakukan sosialisasi kepada orang tua dan memberikan arahan kepada siswanya tentang bullying yang terjadi di sekolah.

\section{DAFTAR PUSTAKA}

Arya, L. (2018). Melawang Bullying initiated an anti-bullying curriculum in schools (W. Suud (ed.)). CV Sepilar Publishing House.

Babarro, I., Andiarena, A., Fano, E., Lertxundi, N., Vrijheid, M., Julvez, J., Barreto, FB, Fossati, S., \& Ibarluzea, J. (2020). Risk and protective factors for bullying at 11 years of age in a spanish birth cohort study. International Journal of Environmental Research and Public Health , 17 (12), 1-19. https://doi.org/10.3390/ijerph17124428

Devita, Y., \& Dyna, F. (2019). Analysis of the Relationship between Child Characteristics and Family Environment with Bullying Behavior. Health Care: Journal of Health , 7 (2), 15-21. https://doi.org/10.36763/healthcare.v7i2.24 
Dharma, KK (2017). Nursing Research Methods Implementing and Applying Research Results (ED 2nd). Media Info Trans.

Kadek, DN, Yanti, E., Putu, NL, Lismawati, \& Mirah, S. (2015). THE RELATIONSHIP OF CHARACTERISTICS AND PERSONALITY OF CHILDREN WITH THE EVENT OF BULLYING IN CLASS V STUDENTS AT "X" SD IN BADUNG REGENCY . 2003 , 9399.

Khairunisa, A. (2014). RELATIONSHIP OF CHARACTERISTICS OF SCHOOL AGE CHILDREN WITH BULLYING BEHAVIOR IN SDN NEGLASARI 1 TANGERANG . 110.

Khoirunnisa, ML, Maula, LH, \& Arwen, D. (2018). The Relationship between Bullying Actions and Anxiety Levels in Vocational High School Students (Smk) Pgri 1 Tangerang. JKFT Journal , 3 (2), 59. https://doi.org/10.31000/jkft.v3i2.1286

Marizki, P. (2018). THE RELATIONSHIP OF CONFIDENCE AND PEOPLE SUPPORT WITH TYPES OF BULLYING BEHAVIOR AT MTSN LAWANG MANDAHILING, SALIMPAUNG DISTRICT, 2017 Marizki Putri College of Health Sciences Purna Bhakti Husada Batusangkar. XII (8), 107-116.

Muhopilah, P., \& Tentama, F. (2019). Factors that influence bullying behavior . November . https://doi.org/10.26555/jptp.v1i2.15132

Novitasari, A., Kirana, W., \& Anggraini, R. (2020). The Relationship between Academic Stress and Family Attachment on Bullying Behavior in Adolescents in Junior High Schools in East Pontianak District. National Conference on Mental Health Nursing (Konas) , 4 (1), 297-305.

Nursalam. (2016). Nursing Management Applications in Professional Nursing Practice (Peni Puji Lestari (ed.); Edition 5).

Sugiyono. (2014). Statistics for research (Ed 4). 
Wakhid, A., Andriani, NS, \& Saparwati, M. (2017). BULLYING BEHAVIOR OF STUDENTS AGED 10-12 YEARS OF THE BULLYING BEHAVIOR AND SOCIAL INTERACTION CAPABILITIES OF 